\title{
Effects of experimental fires on litter decomposition in a seasonally dry Amazonian forest
}

\author{
Juliana M. Silveira*,,${ }^{\prime}$, Jos Barlow $\dagger \dagger$, Alex V. Krusche§, Kate H. Orwinł, Jennifer K. Balch\#,** \\ and Paulo Moutinho††
}

\footnotetext{
* Universidade Federal de Lavras-UFLA, Minas Gerais, 37200-000, Brazil

${ }^{\dagger}$ Museu Paraense Emilio Goeldi-MPEG, Belém, Pará, 66017-970, Brazil

$¥$ Lancaster University, Lancaster Environment Centre, LA1 4YQ, UK

$\S$ Centro de Energia Nuclear na Agricultura - CENA, São Paulo, 13400-970, Brazil

\# Woods Hole Research Center, Falmouth, USA

** Yale University, School of Forestry and Environmental Studies, New Haven, USA

${ }^{\dagger \dagger}$ Instituto de Pesquisa Ambiental da Amazônia - IPAM, 71503-505 Brasília, Brazil

(Accepted 30 June 2009)
}

\begin{abstract}
Litter decomposition is a fundamental process for nutrient cycling but we have a limited understanding of this process in disturbed tropical forests. We studied litter decomposition over a 10-mo period in a seasonally dry Amazon forest in Mato Grosso, Brazil. The study plots ( 50 ha each) included unburned forest (UF), once-burned (BF1) and forest burned annually for 3 y (BF3). We measured understorey density, litter depth, canopy openness, temperature and relative humidity in the plots. Decomposition experiments took place using 720 litterbags filled with approximately $10 \mathrm{~g}$ of natural abscised oven-dried leaves. To test the effects of fire on soil meso- and macrofauna, the litterbags had either a fine ( $2 \mathrm{~mm}$ ) or coarse (with 1-cm holes in side) mesh size. Litterbags were collected and reweighed 2, 4, 6 and 8 mo after being placed on the forest floor. All forest structure variables were significantly different across plots: BF3 was hotter, less humid, had the highest degree of canopy openness, lowest understorey density and the shallowest litter depth. Litter decomposition (mass loss) was similar in the once-burned and unburned plots, but declined more slowly in BF3. In addition, decomposition was slower in fine-mesh litterbags than coarse-mesh litterbags in BF3, but there was no difference between mesh sizes in BF1 and UF. It is likely that changes in forest structure and microclimate explain the lower decomposition rates in BF3. These results show the importance of recurrent fires, but suggest that single understorey fires may not have long-term negative effects on some ecological processes in seasonally dry Amazonian forests.
\end{abstract}

Key Words: Amazon, arthropods, Brazil, decomposition, fire, organic matter

\section{INTRODUCTION}

The nutrient cycle is a vital component of ecosystem functioning and decomposition is an important step (Aber \& Melillo 1991), contributing to the formation and fertility of soils and forming the base of various food webs in tropical forests (Fittkau \& Klinge 1973). The transformation of the organic matter is especially important in tropical forests with infertile soils, where a large proportion of the nutrients are locked up in leaves (Aber \& Melillo 1991). These nutrients are quickly mineralized and absorbed by the roots, especially in the rainy season (Sanderman \& Amundson 2005).

Decomposition is known to be influenced by five intercorrelated factors: climate, soil fertility, organic

\footnotetext{
${ }^{1}$ Corresponding author. Email: silveira.juli@gmail.com
}

matter quality, and the abundance and composition of invertebrates and micro-organisms (Coûteaux et al. 1995, Lavelle et al. 1993). All of these can be affected by disturbance, yet relatively few studies have examined the effects of forest disturbance on decomposition in the humid tropics. The existing studies suggest that heavily impacted areas, such as sites with no vegetation, pasture and small fragments, show slower decomposition rates compared to a primary forest (Kumar \& Deepu 1992, Mesquita et al. 1998). However, secondary forests in advanced stages of succession show similar decomposition rates to primary forests (Barlow et al. 2007, Xuluc-Tolosa et al. 2003). These studies also reveal a marked geographic bias. For example, studies within the Brazilian Amazon are concentrated in forest fragments near Manaus, Amazonas (Didham 1998, Mesquita et al. 1998, Rubinstein \& Vasconcelos 2005, Vasconcelos \& Laurance 2005). 
Accidental fires have become increasingly frequent in Amazonian forest over the past two decades, especially at agricultural frontiers and in severe dry seasons influenced by global climate changes (Alencar et al. 2006). Burning can have an impact on post-fire decomposition by changing forest structure, leading to higher temperatures, lower humidity (Cochrane \& Schulze 1999, Nepstad et al. 1999, Uhl \& Kauffman 1990) and changes in soil proprieties (Schlesinger 1997), all of which act directly on organisms involved in decomposition (Sanderman \& Amundson 2005). Furthermore, even low-intensity fires destroy the leaflitter and soil fauna that live within it (Silveira 2008). Because the soil fauna actively contributes towards decomposition (Coûteaux et al. 1995, Dickinson \& Pugh 1974) it seems likely that fire could also alter decomposition rates by changing faunal populations. However, just one study has examined the impact of wildfires on decomposition in tropical forests, and this was carried out a long (and unspecified) time after the fires occurred, and did not explicitly consider the role of soil fauna in decomposition (Chacón \& Dezzeo 2007).

Soil fauna can be classified on the basis of body size, with mesofauna being organisms with a body width of $<2 \mathrm{~mm}$, and macrofauna being organisms with a body width $>2$ $\mathrm{mm}$. Mesofauna affect decomposition rates by grazing on bacteria, fungi and soil animals, and consuming litter and excreting pellets. Macrofauna transform litter in a similar way, but also physically mix soil organic matter with the mineral horizon (Coûteaux et al. 1995, Dickinson \& Pugh 1974, Wardle 2002). The interaction between both groups can further affect decomposition rates (Bradford et al. 2002, Heneghan et al. 1999, Setälä et al. 1996, Sulkava \& Huhta 1998).

This study aims to provide data on decomposition rates (\% mass loss) and the importance of the leaf-litter fauna in two different experimental fire regimes in a seasonally dry forest in the south of the Brazilian Amazon. Treatments included unburned forest (UF), once-burned (BF1) and forest burned annually for three years (BF3). We test the hypotheses that (1) decomposition is slower in burned forests and (2) decomposition is slower when macrofauna are excluded from the litterbags.

\section{MATERIALS AND METHODS}

\section{Study site}

The study was carried out at Fazenda Tanguro $\left(13^{\circ} 4^{\prime} 35.39^{\prime \prime} \mathrm{S} ; 52^{\circ} 23^{\prime} 8.85^{\prime \prime} \mathrm{W}\right)$ in 150 -ha of Amazonian forest in the municipality of Querencia in the state of Mato Grosso, Brazil, $30 \mathrm{~km}$ north of the forest-cerrado (Brazilian savanna) boundaries. The vegetation in the study site consists of a closed-canopy forest, with tree height reaching $18-20 \mathrm{~m}$, with a few taller emergents (Balch et al. 2008, Ivanauskas et al. 2003). Vegetation in these forests is lower in diversity than more humid tropical forests (Balch et al. 2008). Oxisols are predominant, with high $\mathrm{Al}$ content and low fertility (Radam Brasil 1974). Climate is humid tropical, type Aw according to Köeppen's classification (Radam Brasil 1974). Average annual rainfall is c. $1500 \mathrm{~mm}$. There is a marked dry season from May to September, where rainfall often falls below $10 \mathrm{~mm} \mathrm{mo}^{-1}$ (Balch et al. 2008).

The 150-ha site was divided into three 50-ha plots in 2004, composed of unburned forest (UF), once-burned (BF1), and forest burned annually for 3 y (BF3). Trails were cut every $50 \mathrm{~m}$ in $\mathrm{N}-\mathrm{S}$ directions, and marked every $50 \mathrm{~m}$ in $\mathrm{E}-\mathrm{W}$ directions in the three plots, creating a grid that was used for data collection. All experimental burns took place at the end of the dry season (AugustSeptember). During all years, fires were set using kerosene drip torches along the $\mathrm{N}-\mathrm{S}$ trails. A total of $10 \mathrm{~km}$ of firelines were set per plot during 3-4 consecutive days from $9 \mathrm{~h} 00$ to $16 \mathrm{~h} 00$. These fires often smouldered or went out during the humid nights, and were therefore relit the following day. Fires typically burned leaf litter and fallen twigs and branches, but not the standing trees (see Balch et al. 2008 for more details).

This study was conducted from December 2006 to August 2007 (before the 2007 burning); therefore the two burnt treatments had either been burnt once in 2004 and were measured 28 mo after the last fire (BF1), or had been burnt once per year for the last $3 \mathrm{y}$, with measurements taken 4 mo after the last fire (BF3). The site was surrounded by a large expanse of native forest on three sides, and one side was adjacent to pasture (Balch et al. 2008). We avoided edge effects by placing litterbags at least $100 \mathrm{~m}$ from the pasture and adjacent treatments.

\section{Environmental variables}

We recorded three forest structural variables that indirectly affect decomposition: litter depth, understorey vegetation density and canopy openness. Those variables were recorded in $3 \times 3-\mathrm{m}$ quadrats at each grid point $(\mathrm{n}=162$ for each plot). Litter depth was measured with a ruler at the four corners of each quadrat. Understorey density was indexed by counting how many times live vegetation touched a pole that was $2.5 \mathrm{~m}$ in height and 3.5 $\mathrm{cm}$ in diameter, placed upright at the four corners of each quadrat. Canopy openness was calculated using digital hemispherical photographs taken in the centre of each quadrat. For each of these measurements, the average score was used to characterize each $3 \times 3$-m quadrat, and the average across all representative quadrats was used to characterize the environmental conditions in each forest plot. All data were collected in March (rainy season) and 


\begin{tabular}{|c|c|c|c|}
\hline & UF & BF1 & BF3 \\
\hline \multicolumn{4}{|l|}{ February 2007} \\
\hline Canopy openness & $6.5 \pm 8.4^{\mathrm{a}}$ & $13.6 \pm 12.7^{\mathrm{b}}$ & $22.2 \pm 20.2^{c}$ \\
\hline Understorey density & $3.1 \pm 1.5^{\mathrm{a}}$ & $2.5 \pm 1.7^{\mathrm{b}}$ & $0.9 \pm 1.6^{\mathrm{c}}$ \\
\hline Litter depth & $4.4 \pm 1.9^{\mathrm{a}}$ & $2.9 \pm 1.4^{\mathrm{b}}$ & $1.4 \pm 0.8^{\mathrm{c}}$ \\
\hline \multicolumn{4}{|l|}{ August 2007} \\
\hline Canopy openness & $6.6 \pm 7.6^{\mathrm{a}}$ & $14.8 \pm 11.9^{b}$ & $25.8 \pm 21.1^{\mathrm{c}}$ \\
\hline Understorey density & $3.3 \pm 1.1^{\mathrm{a}}$ & $2.7 \pm 1.5^{\mathrm{b}}$ & $0.8 \pm 1.0^{\mathrm{c}}$ \\
\hline Litter depth & $4.0 \pm 1.6^{\mathrm{a}}$ & $2.0 \pm 1.6^{\mathrm{b}}$ & $1.0 \pm 0.8^{c}$ \\
\hline
\end{tabular}

August (dry season). Temperature and relative humidity were recorded at 15 randomly located points within each treatment, using T-RH sensors (Onset Computer Corporation, Pocasset, MA, USA) that took readings at midday throughout the experiment.

\section{Litterbags}

Two litter bags (representing one coarse and one fine mesh size) were placed in 120 randomly selected grid points in each plot $(\mathrm{n}=240$ per plot and 720 in total). Litterbags $(25 \times 25 \mathrm{~cm})$ were made of 2 -mm nylon mesh, preventing the entrance of macrofauna but allowing mesofauna to enter. In half of the litterbags we made three $1-\mathrm{cm}^{2}$ perforations on each side to facilitate the colonization of macrofauna (cf. Didham 1998). Litterbags werefilled with approximately $10 \mathrm{~g}$ of naturally abscised leaves collected randomly in primary forest and oven dried for $4 \mathrm{~d}$ at $60^{\circ} \mathrm{C}$. Litterbags were placed in the forest in early December 2006, during the rainy season. At 2-mo intervals we collected the coarse- and fine-mesh litterbags from 30 randomly selected grid points from within the three plots. Litterbags were oven dried for $4 \mathrm{~d}$ at $60{ }^{\circ} \mathrm{C}$ and reweighed to the nearest $0.1 \mathrm{~g}$ after removing fine roots, invertebrates and mud. Due to damage (mostly by leaf cutter ants) only 531 litter bags were analysed, but the sample design remained balanced across factors: sampling period $(\mathrm{n}=134,143,116,138$ for periods $1-4)$, fire treatment $(\mathrm{n}=180,170,181$ for unburned, once and thrice-burned forest, respectively) and mesh types ( $n=255$ and 276 for fine and coarse mesh types, respectively).

\section{Data analyses}

The difference between forest structural variables, temperature and relative humidity in the three treatments was examined using one-way ANOVA after checking data for normality. Although the variance in relative humidity was lower in the control plots than the burned treatments, we continue to use ANOVA as the results were the same using non-parametric tests (e.g. Kruskal-Wallis) and it allows Tukey's post hoc comparison between treatments. Decomposition rates were expressed as remaining dry weight in the litterbags after $2,4,6$ and 8 mo in the field. We converted litter dry weights to the proportion of litter weight remaining in the litterbags. The effects of fire treatment (UF, BF1 and BF3), mesh size (large and small), and time period (four measurements) on the proportion of litter weight remaining were examined using Analysis of Deviance with the 'glm' and 'anova' functions in the R statistical environment (R Development Core Team 2008). We used a quasi-binomial error structure appropriate for the analysis of proportion data, and used the F-test to examine significance (Crawley 2007), where $F$ is the ratio of the between-group variation divided by the within-group variation.

\section{RESULTS}

\section{Environmental variables}

All forest structural variables used were significantly different across plots $(\mathrm{P}<0.001)$. BF1 showed intermediate values for all of them (Table 1). BF3 forest had the highest degree of canopy openness, the lower understorey density and the smallest litter depth, indicating that three successive fire events had drastically affected forest structure. Temperature in UF and BF1 was similar overall, while BF3 was significantly hotter than both other treatments in almost all months (Figure 1). Relative humidity was similar in UF and BF1 and higher than BF3 in all months except August (Figure 1).

\section{Litter decomposition}

Litter decomposition was strongly affected by sampling period $\left(\mathrm{F}_{3,520}=192 ; \mathrm{P}<0.001\right)$, fire treatment $\left(\mathrm{F}_{2,523}=\right.$ 24.3; $\mathrm{P}<0.001)$, and mesh size $\left(\mathrm{F}_{1,525}=24.1\right.$; 

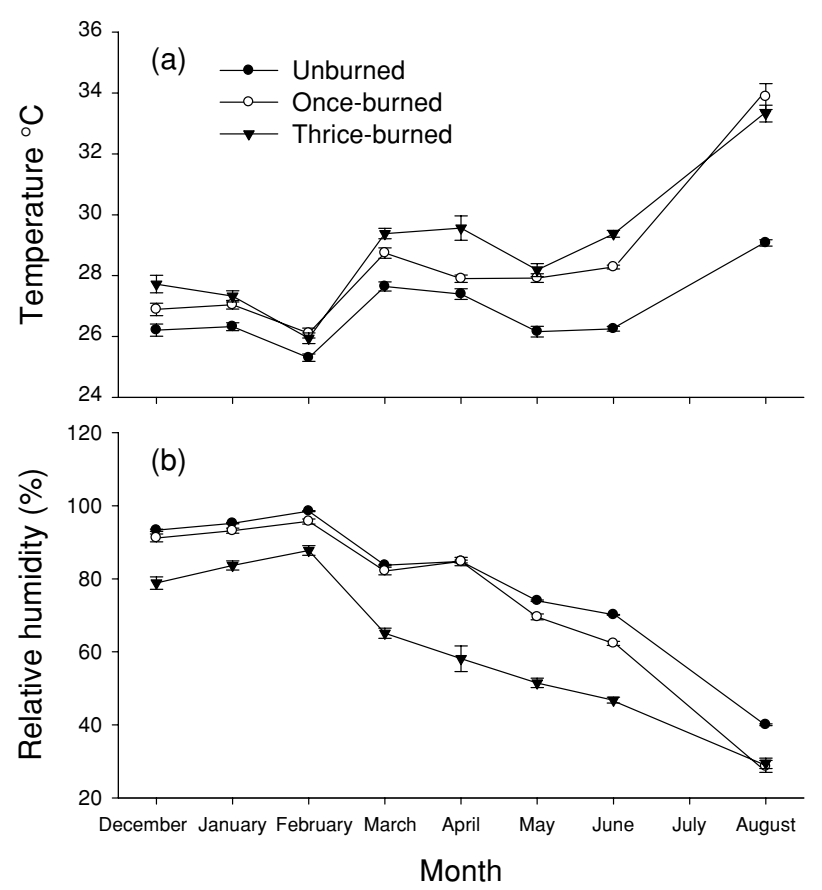

Figure 1. Mean ( \pm SE) temperature (a) and relative humidity (b) in unburned forest, once-burned forest and thrice-burned forest. Tukey's posthoc tests revealed the following significant differences: thrice-burned was different from the unburned treatment in all months for temperature and relative humidity; for temperature, once-burned was significantly different from thrice-burned in December, March, April and June, and was significantly different from unburned in all months except December and April. For relative humidity, once-burned was significantly different from thrice-burned in all months except August, and was significantly different from unburned in February, May, June and August.

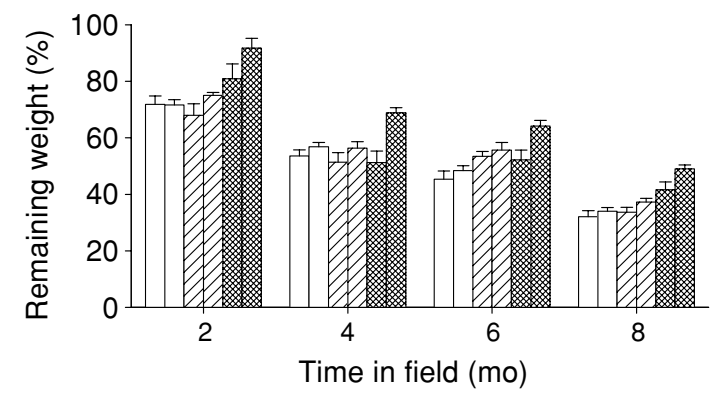

Figure 2. Mean remaining litter weight ( $\% \pm \mathrm{SE})$ in unburned (open bars), once-burned (diagonal hatching) and thrice-burned (cross-hatched) forest, over four sampling periods. Within each sample period and fire treatment, coarse-mesh litter bags are represented by the bar on the left, and fine-meshed litter bags by the bar on the right.

$\mathrm{P}<0.001$ ) (Figure 2). There were significant interactions for fire treatment $\times$ mesh size $\left(\mathrm{F}_{2,522}=7.8 ; \mathrm{P}<0.001\right)$, and fire treatment $\times$ sampling period $\left(\mathrm{F}_{6,513}=2.7\right.$; $P=0.012$ ). Interactions between sampling period $x$ mesh size and treatment $\times$ sampling period $\times$ mesh size were not significant $(\mathrm{P}>0.05)$. The differences of mass loss between UF and BF1 were not significant $(\mathrm{P}>0.05)$, but BF3 was significantly different from both $(\mathrm{P}<0.001)$ based on the GLM summary statistics. All comparisons of mass loss between sampling periods were significantly different from the first sample $(\mathrm{P}<0.001)$.

Because of the significant interactions between fire treatment $\times$ sampling period, we conducted separate tests for each of the four sampling periods. Fire treatment was highly significant in the first $\left(\mathrm{F}_{2,130}=8.9\right.$, $\mathrm{P}<0.001)$, third $\left(\mathrm{F}_{2,112}=10.5, \mathrm{P}<0.001\right)$ and fourth $\left(\mathrm{F}_{2,134}=24.1, \mathrm{P}<0.001\right)$ sample period, and narrowly insignificant in the second sample period $\left(\mathrm{F}_{2,139}=2.7\right.$, $\mathrm{P}=0.07)$. Mesh size was significant $(\mathrm{P}<0.05)$ in all sampling periods. The fire treatment $\times$ mesh size interaction was only significant in the second sample $\left(\mathrm{F}_{2,137}=4.5, \mathrm{P}=0.01\right)$.

\section{DISCUSSION}

This experiment examined whether fire can affect decomposition rates in seasonally dry tropical forests. We do not attempt to compare between fire regimes, as our comparisons are limited by the different time since the last fire in the burned plots (28 mo in BF1 and 4 mo in BF3). However, our results do highlight some important patterns, and show that 28 mo after a single low-intensity fire some aspects of forest functioning that are necessary for nutrient cycling are restored. This was not the case 4$12 \mathrm{mo}$ after the last fire in forest that was experimentally burned three times in as many years.

\section{Environmental variables}

Fire had a clear effect on canopy openness, understorey and litter depth, with greater effects seen in BF3 than in $\mathrm{BF} 1$. This may reflect either the time since the last fire, or that burning multiple times has a more severe effect on forest structure. By increasing the sunlight reaching the floor, canopy gaps favour the rapid growing up of shrubs, lianas and large herbs (Denslow \& Hartshorn 1994), leading to an increase in understorey density (Barlow \& Peres 2004). However, our measurements did not detect any increase in understorey density 1 y (BF3) or even 3 y (BF1) after the last fire. These results suggest that seasonally dry Amazonian forests that are located close to cerrado (Brazilian savanna) may have a different dynamic of regeneration after disturbance from humid forests further from the forest-cerrado transition zone. Litter depth also was higher in UF, intermediary in BF1 and lower in BF3, and these results can be linked to the time since the most recent fire, as BF1 had more time to accumulate leaf-litter whileBF3 did not. Temperature and humidity in our surveyed plots appeared strongly linked to changes in the forest structure; UF generally had the 
lowest temperatures and highest relative humidity, BF1 showed intermediate values, and BF 3 showed the highest temperatures and lowest relative humidity. Temperatures are generally $3-4{ }^{\circ} \mathrm{C}$ hotter in canopy gaps (Holdsworth \& Uhl 1997), also increasing the temperature of the forest in general (Barlow et al. 2007, Nepstad et al. 1999, Uhl \& Kauffman 1990).

\section{Litter decomposition}

There is no evidence that fire affected decomposition 28 mo after a single fire, and these forests appeared to function in a similar way to unburned forest. The fact that there were significant differences in forest structure but no difference in decomposition between UF and BF1 plots suggests that below-ground leaf-litter decomposition processes may not be strongly coupled with above-ground forest structure. These results are comparable to those from Chacón \& Dezzeo (2007), in which forests showed similar mass loss a long time after the last fire. Our results also demonstrate that recurrent fires can result in a system with reduced litter decomposition rates. This effect may partly be due to the higher temperatures and lower relative humidity seen in BF3 (Figure 1), which may have resulted in decomposition being more limited by water. There are no comparable studies on litter decomposition in tropical forests that have succumbed to recurrent fires.

Litter biota provides a second potential explanation for differences in decomposition rates between the fire treatments. Macrofauna appeared to play a much greater role in decomposition in BF3 than in either BF1 or UF, as macrofaunal exclusion appeared to result in lower decomposition rates in $\mathrm{BF} 3$, but had no effect in $\mathrm{BF} 1$ or UF (Figure 2). However, the role of macrofauna does not explain all of the reduction in decomposition in $\mathrm{BF} 3$, as the decomposition rate in the fine-mesh bags (excluding macrofauna) were still lower in $\mathrm{BF} 3$ than other fire treatments across most of the seasonal samples. This result suggests that annual burning may reduce the biomass or alter the composition of soil microbes, and/or mesofauna, all of which could have an effect on decomposition rates (Bradford et al. 2002, Waldrop et al. 2000). Other studies that have examined the effect of soil fauna on decomposition in the tropics have also found varying results. For example, litter mass loss was not found to be related to the population of litter-feeding invertebrates in two studies based in Malaysia (Anderson et al. 1983) and the central Brazilian Amazon (Didham 1998), but was found to be related to mesh size in Nigeria (Swift et al. 1981), Pará, Brazil (Nepstad et al. 2002) and Amazonas, Brazil (Vasconcelos \& Laurance 2005).

The similar decomposition rates in BF1 and UF suggest that one single fire may represent a disturbance of relatively low impact to nutrient cycling, reflecting results from old secondary forests (Barlow et al. 2007, Ewel 1976, Loranger et al. 2002, Swift et al. 1981, Xuluc-Tolosa et al. 2003), selective logging (Anderson et al. 1983, Burghouts et al. 1992), large forest fragments (Didham 1998, Mesquita et al. 1998, Rubinstein \& Vasconcelos 2005, Vasconcelos \& Laurance 2005), severe dry seasons (Nepstad et al. 2002), and old burned forest (Chacón \& Dezzeo 2007). However, decomposition rates were considerably lower in the recurrently burned plot (BF3), suggesting that the impact of these fires on leaf-litter decomposition is comparable to those found following the most severe forms of forest disturbance, including deforestation (Ewel 1976), conversion to pasture (Kumar \& Deepu 1992) or plantations (Barlow et al. 2007), and the creation of very small fragments (Didham 1998, Rubinstein \& Vasconcelos 2005).

\section{CONCLUSIONS}

Annually burned, seasonally dry Amazon forests apparently present a negative fire feedback, as low litter production acts to reduce fuel input (Balch et al. 2008). However, this study shows that important ecosystem functions such as decomposition are not recovered within $1 \mathrm{y}$ of the most recent recurrent fire. This change in function appeared to be related to changes in both the microclimate and forest structure, although the role of mesh size indicates that changes in the litter and soil biota caused by the fire treatment may also be important. The similarity of decomposition in once-burned forests 28 mo after the most recent fire compared with unburned forest suggests that one single fire does not have longterm negative effects on at least some ecological processes. However, we would caution against extrapolating these results from experimental fires in very seasonal forests to other situations in Amazonia, and suggest that more work is required to fully understand the scale of effects of fire on ecosystem functioning in these fire-sensitive ecosystems.

\section{ACKNOWLEDGEMENTS}

J. M. Silveira gratefully acknowledges the Conselho Nacional de Pesquisa Científica $(\mathrm{CNPq})$ which supported her Ph.D. research, and the IPAM field staff who helped collect the data. Grupo Amaggi provided logistical support. Funding for the experimental fires was provided by the David and Lucile Packard Foundation, NASA LBAECO program, and NSF Biocomplexity in the Environment and Ecosystems programs. An anonymous reviewer provided comments that improved the manuscript. 


\section{LITERATURE CITED}

ABER, J. D. \& MELILLO, J. M. 1991. Terrestrial ecosystems. Saunders College Publishing, Philadelphia. 436 pp.

ALENCAR, A., NEPSTAD, D. \& DIAZ, M. C. V. 2006. Forest understory fire in the Brazilian Amazon in ENSO and non-ENSO years: area burned and committed carbon emissions. Earth Interactions 10:1-16.

ANDERSON, J. M., PROCTOR, J. \& VALLACK, H. W. 1983. Ecological studies in four contrasting lowland rain forests in Gunung Mulu National Park, Sarawak: III. Decomposition processes and nutrient losses from leaf litter. Journal of Ecology 71:503-527.

BALCH, J. K., NEPSTAD, D., BRANDO, P. M., CURAN, L. M., PORTELA, O. F., DE CARVALHO, O. \& LEFEBVRE, P. 2008. A negative fire feedback in a transitional forest of southeastern Amazonia. Global Change Biology 14:1-12.

BARLOW, J. \& PERES, C. A. 2004. Ecological responses to El Niñoinduced surface fires in central Amazonia: management implications for flammable tropical forests. Philosophical Transactions of the Royal Society of London B 359:367-380.

BARLOW, J., GARDNER, T. A., FERREIRA, L. V. \& PERES, C. A. 2007. Litter fall and decomposition in primary, secondary and plantation forests in the Brazilian Amazon. Forest Ecology and Management 247:91-97.

BRADFORD, M. A., TODORFF, G. M., EGgERS, T., JONES, T. H. \& NEWINGTON, J. E. 2002. Microbiota, fauna and mesh size interactions in litter decomposition. Oikos 99:317-323.

BURGHOUTS, T., EARNSTING, G., KORTHLS, G. \& DE VRIES, T. 1992. Litterfall, leaf litter decomposition and litter invertebrates in primary and selectively logged dipterocarp forest in Sabah, Malaysia. Philosophical Transactions of the Royal Society of London 335:407416.

CHACÓN, N. \& DEZZEO, N. 2007. Litter decomposition in primary forest and adjacent fire-disturbed forests in the Gran Sabana, southern Venezuela. Biology and Fertility of Soils 43:815-821.

COCHRANE, M. \& SCHULZE, M. D. 1999. Fire as a recurrent event in tropical forests of the eastern Amazon: effects on forest structure, biomass, and species composition. Biotropica 31:2-16.

COÛTEAUX, M. M., BOTTNER, P.\&BERG, B. 1995. Litter decomposition, climate and litter quality. Tree 10:63-66.

CRAWLEY, M. J. 2007. The R book. John Wiley \& Sons Ltd, Chichester. $941 \mathrm{pp}$.

DENSLOW, J. S. \& HARTSHORN, G. S. 1994. Treefall gap environments and forest dynamic processes. Pp. 120-127 in McDade, L. A., Bawa, K., Hespenheide, H. \& Hartshorn, G. S. (eds). La Selva: ecology and natural history of a neotropical rain forest. University of Chicago Press, Chicago.

DICKINSON, C. H. \& PUGH, G. J. F. 1974. Biology of plant litter decomposition. Academic Press, London. 175 pp.

DIDHAM, R. K. 1998. Altered leaf-litter decomposition rates in tropical forests fragments. Oecologia 116:397-406.

EWEL, J. J. 1976. Litter fall and leaf decomposition in a tropical forest succession in eastern Guatemala. Journal of Ecology 64:293-308.

FITTKAU, E. J. \& KLINGE, H. 1973. On biomass and trophic structure of the central Amazonian rain forest ecosystem. Biotropica 5:2-14.
HENEGHAN, L., COLEMAN, D.C., ZOU, X., CROSSLEY, D. A. J. \& HAINES, B. L. 1999. Soil microarthropod contributions to decomposition dynamics: tropical temperate comparisons of a single substrate. Ecology 80:1873-1882.

HOLDSWORTH, A. R. \& UHL, C. 1997. Fire in Amazonian selectively logged rain forest and the potential for fire reduction. Ecological Applications 7:713-725.

IVANAUSKAS, N. M., MONTEIRO, R. \& RODRIGUES, R. R. 2003. Alterations following a fire in a forest community of Alto Xingu. Forest Ecology and Management 184:239-250.

KUMAR, B. M.\& DEEPU, J. K. 1992. Litter production and decomposition dynamics in moist deciduous forests of the West Ghats of Peninsular India. Forest Ecology and Management 50:181-201.

LAVELLE, P., BLANCHART, E., MARTIN, A., MARTIN, S. \& SPAIN, A. 1993. A hierarchical model for decomposition in terrestrial ecosystems: application to soils of humid tropics. Biotropica 25:130150.

LORANGER, G., PONGE, J.-F., IMBERT, B. \& LAVELLE, P. 2002. Leaf decomposition in two semi-evergreen tropical forests: influence of litter quality. Biology and Fertility of Soils 35:247-252.

MESQUITA, R. C. G., WORKMAN, S. W. \& NEELY, C. L. 1998. Slow decomposition in a Cecropia-dominated secondary forest of Central Amazonia. Soil Biology and Biochemistry 30:167-175.

NEPSTAD, D., VERÍSSIMO, A., ALENCAR, A., NOBRE, C., LIMA, E., LEFEBVRE, P., SCHLESINGER, P., POTTER, C., MOUTINHO, P., MENDOZA, E., COCHRANE, M. \& BROOKS, V. 1999. Large-scale impoverishment of Amazonian forests by logging and fire. Nature 38:505-508.

NEPSTAD, D. C., MOUTINHO, P., DIAS-FILHO, M. B., DAVIDSON, E., CARDinOt, G., MARKEWITZ, D., FIGUEIREDO, R., VIANNA, N., CHAMBERS, J., RAI, D., GUERREIROS, J. B., LEFEBVRE, P., STERNBERG, L., MOREIRA, M., BARROS, L., ISHIDA, F. Y., TOHLVER, I., BELK, E., KALIF, K. \& SCHALBE, K. 2002. The effects of partial throughfall exclusion on canopy processes, aboveground production and biogeochemistry of an Amazon forest. Journal of Geophysical Research, 107(D20):8085, doi:10.1029/2001JD000360.

RADAM, BRASIL. 1974. Projeto RADAM BRASIL. DNP/MME, Folha SA 22. Rio de Janeiro. 478 pp.

RUBINSTEIN, A. \& VASCONCELOS, H. L. 2005. Leaf-litter decomposition in Amazonian forest fragments. Journal of Tropical Ecology 21:699-702.

SANDERMAN, J. \& AMUNDSON, R. 2005. Biogeochemistry of decomposition and detrital processing. Pp. 249-316 in Schlesinger, W. H. (ed). Biogeochemistry - treatise on geochemistry, Elsevier, Amsterdam.

SCHLESINGER, W. 1997. The biosphere: biogeochemical cycling on land. Pp. 166-223 in Schlesinger, W. (ed). Biogeochemistry: an analysis of global change. (Second edition). Academic Press, San Diego.

SETÄLÄ, H., MARSHALL, V. G. \& TROFYMOW, J. A. 1996. Influence of body size of soils fauna on litter decomposition and $15 \mathrm{~N}$ uptake by poplar in a pot trial. Soil Biology and Biochemistry 28:16611675.

SILVEIRA, J. M. 2008. Fogo recorrente na serrapilheira: conseqüências para artrópodes, decomposição da matéria orgânica e mineralização 
de carbono e nitrogênio em uma floresta de transição da Amazônia. Tese de Doutorado. Museu Paraense Emilio Goeldi. 186 pp.

SUlKAVA, P. \& HUHTA, V. 1998. Habitat patchiness affects decomposition and faunal diversity: a microcosm experiment on forest floor. Oecologia 116:390-396.

SWIFT, M. J., RUSSELL-SMITH, A. \& PERFECT, T. J. 1981. Decomposition and mineral-nutrient dynamics of plant litter in a regeneration bush-fallow in sub-humid, tropical Nigeria. Journal of Ecology 69:981-995.

UHL, C. \& KAUFFMAN, J. B. 1990. Deforestation, fire susceptibility, and potential tree responses to fire in the eastern Amazon. Ecology 71:437-449.

VASCONCELOS, H. L. \& LAURANCE, W. F. 2005. Influence of habitat, litter type and soil invertebrates on leaf-litter decomposition in a fragmented Amazonian landscape. Oecologia 144:456462.

WALDROP, M. P., BALSER, T. C. \& FIRESTONE, M. K. 2000. Linking microbial composition to function in a tropical soil. Soil Biology and Biochemistry 32:1837-1846.

WARDLE, D. A. 2002. Communities and ecosystems: linking the aboveground and belowground components. Princeton University Press, Princeton. 392 pp.

XULUC-TOLOSA, F. J., VESTER, H. F. M., RAMÍREZMARCIAL, M., CASTELLANOS-ALBORES, J. \& LAURANCE, D. 2003. Leaf litter decomposition of tree species in three successional phases of tropical dry secondary forest in Campeche, Mexico. Forest Ecology and Management 174:401412. 